\title{
NOTES ON THE CONTRIBUTORS
}

Yukiko Asada is Associate Professor in the Department of Community Health and Epidemiology at Dalhousie University. She is the author of Health Inequality: Morality and Measurement (2007). Her work investigates ethical assumptions underlying quantitative methods used in population health.

Gillian Brock is Associate Professor in the Philosophy Department at the University of Auckland. She has written extensively on issues of global justice. She is the author of Global Justice: A Cosmopolitan Account (2009) and editor or co-editor of Current Debates in Global Justice (2005), The Political Philosophy of Cosmopolitanism (2005), Necessary Goods: Our Responsibilities to Meet Others' Needs (1998) and Global Health and Global Health Ethics (2011).

Garrett Wallace Brown is Senior Lecturer in Political Theory and Global Ethics in the Department of Politics, University of Sheffield. His publications include work on cosmopolitanism, globalisation, global justice and global health governance. He has recently published Grounding Cosmopolitanism (Edinburgh University Press, 2009) and The Cosmopolitanism Reader (2010), and is currently publishing Global Health Policy.

Ryoa Chung is Associate Professor at the Department of Philosophy of the Université de Montréal. Her work published in English has appeared in Critical Review of International Social and Political Philosophy, Public Health Ethics and Canadian Journal of Philosophy. She is currently co-editing Éthique des relations internationales (forthcoming: 2013). 
Phillip Cole has written on human rights and international migration, including the right to healthcare. His most recent work is Debating the Ethics of Immigration: Is there a Right to Exclude? (2011) with Christopher Heath Wellman. He is Visiting Professor in Applied Philosophy at Newport University, Wales.

Lisa Eckenwiler is Associate Professor of Philosophy in the Department of Philosophy at George Mason University. She also serves as Director of Health Ethics. Her current research focuses on ethical issues at the intersection of long-term care, health-worker migration and global health inequities. Her second book, Long Term Care, Globalization, and Justice, is forthcoming.

Nicole Hassoun is an Assistant Professor in Philosophy at Carnegie Mellon University. She is affiliated with Carnegie Mellon's Program on International Relations and the University of Pittsburgh's Center for Bioethics and Health Law. In 2009-10 she held a post-doctoral position at Stanford University and visited at the United Nations' World Institute for Development Economics Research. She has also been a visiting scholar at the Center for Poverty Research in Austria and the Center for Advanced Studies in Frankfurt. Her book, Globalization and Global Justice: Shrinking Distance, Expanding Obligations, is forthcoming.

Daniel M. Hausman is the Herbert A. Simon and Hilldale Professor of Philosophy at the University of Wisconsin-Madison. His research has centred on epistemological, metaphysical and ethical issues lying at the boundaries between economics and philosophy. His most recent book, just published, is Preference, Value, Choice and Welfare.

Matthew R. Hunt is an Assistant Professor in the School of Physical and Occupational Therapy and Affiliate Member of the Biomedical Ethics Unit at McGill University, Montreal. His research focuses on ethical issues related to two domains: global health engagement, and rehabilitation care and professions.

Angela Kaida is a global health epidemiologist interested in the linkages between HIV and reproductive health. She is a Canada Research Chair (Tier 2) in Global Perspectives in HIV and Sexual 
and Reproductive Health and an Assistant Professor in the Faculty of Health Sciences at Simon Fraser University.

Eszter Kollar is Adjunct Assistant Professor, International Affairs, John Cabot University, as well as a Research Fellow at the Center for Ethics and Global Politics/Faculty of Political Science, LUISS University, Rome. Before that, she held a post-doctoral fellowship at the Hoover Chair, Catholic University of Louvain. She is co-editor, with Miriam Ronzoni, of a symposium on Gillian Brock's Global Justice: A Cosmopolitan Account - Global Justice: Theory Practice Rhetoric (2010).

Patti Tamara Lenard is Assistant Professor of Applied Ethics at the Graduate School of Public and International Affairs, University of Ottawa. Her first book is Trust, Democracy and Multicultural Challenges.

Adina Preda is a research fellow in the Centre for Research in Ethics at the University of Montreal (CRÉUM), currently working on a collaborative project on health equity (M-HERC). Prior to this, she was a Hoover fellow at the Hoover Chair, Catholic University of Louvain and a lecturer in political theory at University College Dublin.

Christine Straehle is Assistant Professor of Applied Ethics at the Graduate School of Public and International Affairs, University of Ottawa.

Sridhar Venkatapuram is a Wellcome Trust Research Fellow in Ethics at the London School of Hygiene and Tropical Medicine, and an Affiliated Lecturer at Cambridge University. His current research is at the intersection of health sciences and social justice philosophy. His first monograph, Health Justice: An Argument from the Capabilities Approach, was published in 2011.

Kristin Voigt is a post-doctoral fellow at McGill University, jointly in the Department of Epidemiology, Biostatics and Occupational Health and the Biomedical Ethics Unit. Her research focuses on egalitarian theories of social justice and egalitarian concerns around health policy. 
